\title{
LIFE HISTORY TRAITS OF NERETVA ROACH Rutilus basak (Heckel, 1843) (Pisces, Cyprinidae): BIOLOGICAL AND ECOLOGICAL CONTRIBUTION FOR BIODIVERSITY CONSERVATION OF FRESHWATER FISH
}

\author{
Pero Tutman $^{1 *}$, Sanja Matič-Skoko ${ }^{1}$, Adem Hamzić ${ }^{2}$, Jakov Dulčić ${ }^{1}$, Branko Glamuzina ${ }^{3}$ \\ ${ }^{1}$ Institute of Oceanography and Fisheries, 21000 Split, Croatia. \\ ${ }^{2}$ University of Sarajevo, Faculty of Science, 71000 Sarajevo, Bosnia and Herzegovina \\ 3University of Dubrovnik, Department of Aquaculture, 20000 Dubrovnik, Croatia \\ ${ }^{*}$ Corresponding Author, Email: tutman@izor.hr
}

\section{ARTICLE INFO}

Received: 24 October 2017

Received in revised form: 5 March 2018

Accepted: 6 March 2018

Online first: 11 May 2018

\section{Keywords:}

Adriatic Sea watershed

Status

Distribution

Threats

Conservation

\begin{abstract}
This paper is a review of the relevant scientific literature on the present status, distribution, habitat, ecological traits, population structure and threats of Neretva roach Rutilus basak (Heckel, 1843). The species inhabits a restricted area of the Adriatic Sea watershed in Croatia and Bosnia and Herzegovina. The major threats are habitat loss caused by significant hydrological changes in the water regime in the area of distribution and the introduction of non-indigenous species. Still, $R$. basak is quite widespread and often abundant. Information brought together in this study will improve our knowledge about this species.
\end{abstract}

How to Cite

Tutman, P., Matič-Skoko, S., Hamzić, A., Dulčić, J., Glamuzina, B. (2018): Life history traits of Neretva roach Rutilus basak (Heckel, 1843) (Pisces, Cyprinidae): Biological-ecological contribution for biodiversity conservation of freshwater fish. Croatian Journal of Fisheries, 76, 66-71. DOI: 10.2478/ cjf-2018-0008.

\section{INTRODUCTION}

Freshwater ecosystems in the Adriatic Sea basin are especially rich in endemic species and so they are unique and of major importance for conservation (Crivelli and Maitland 1995a, b; Mrakovčić et al., 1995; Crivelli, 1996; Kottelat and Freyhof, 2007). This region has a very high ratio of rare, threatened and endemic freshwater fishes (Mrakovčić et al., 1995; Mrakovčić et al., 2006; Glamuzina et al., 2013), it is often considered a biodiversity "hot spot" (Darwall et al., 2014; Buj et al., 2015) and so it is of particular interest for conservation purposes. Despite the importance of endemic species for biodiversity conservation in Europe, many Adriatic freshwater fish species have been inadequately studied and their distribution, ecology and population trends are largely unknown. Neretva roach Rutilus basak, a freshwater fish species distributed in the Adriatic Sea watershed of Croatia and Bosnia and Herzegovina, is studied in this paper (Tutman and Glamuzina, 2007; Matić-Skoko et al., 2011; Tutman et al., 2012). Although it is relatively common and abundant (Matić-Skoko et al., 2011; Ćaleta et al., 2015), scientific knowledge on this species is still insufficient and partly obsolete. There are studies on general biological and ecological data (Vuković and Ivanović, 1970; Vuković and 
Ivanović, 1971; Vuković, 1977; Sofradžija, 2009) and overall faunistic records (Kosorić, 1978; Kosorić et al., 1983). There is also data on age structure (Aganović and Kapetanović, 1978). However, the characteristics useful for conservation management such as distribution data, population trends, sensitivity to the invasion of non-indigenous species, pollution, hydrological changes have not been studied systematically (Glamuzina et al., 2001; Tutman et al., 2013). Only recently, length-weight relationship (Dulčić et al., 2009), some biological and ecological characteristics and the conservation status (Tutman and Glamuzina, 2007), as well as the population structure, age and growth pattern (MatićSkoko et al., 2011) have been analysed for the population of the Hutovo Blato wetland. Additional data, like information on the main threats, is derived from different ichthyological monitoring surveys (Glamuzina et al., 2001; Tutman et al., 2013). The purpose of this study is to give a comprehensive review of biological and ecological data, habitat preferences and conservation status of Neretva roach compiled from literature data. This review might serve as a foundation for future research aimed at better and effective management and conservation programs.

\section{MATERIALS AND METHODS}

In total, 19 literature sources were analysed, 12 presenting original data.

\section{RESULTS}

\section{Conservation status}

Rutilus basak (Fig. 1) is listed as Least Concern (LC) by the last assessment of the IUCN in the year 2006 (Crivelli, 2006). In the Red Book of Freshwater Fish of Croatia, $R$. basak is listed as Near Threatened (NT) (Mrakovčić et al., 2006), while as Endangered (EN) in the Red List of Fauna of Federation of Bosnia and Herzegovina as part of the Republic of Bosnia and Herzegovina (Škrijelj et al., 2013). Analysis of the observed category divergence in the status rank indicates a lack of harmonized methods that are used to assess species status as rational numbers are not given in the Bosnia and Herzegovina national Red List assessment. This results in an altered status rank without a clearly understandable explanation of the underlying reasons for the species status. In order to avoid an overestimation or underestimation of the regional extinction risk of a species, the Guidelines for the Application of IUCN Red List Criteria at Regional Level should be applied (IUCN, 2016).

\section{Distribution}

In Croatia, $R$. basak is distributed in lakes and small rivers

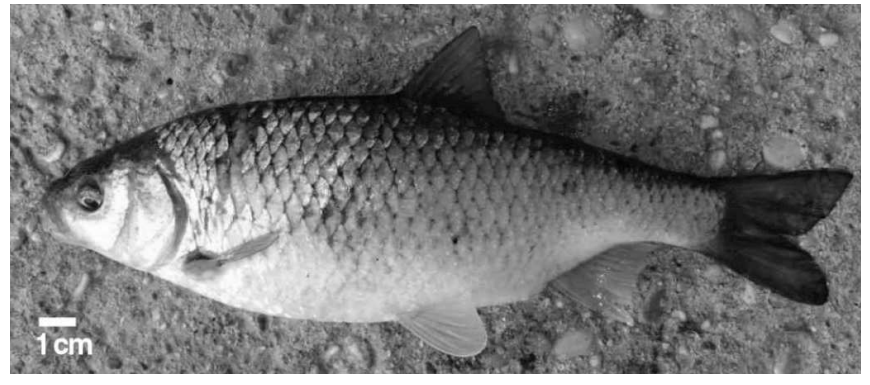

Fig 1. Neretva roach Rutilus basak (Heckel, 1843), $220 \mathrm{~mm}$ TL from the Hutovo Blato wetland, Bosnia and Herzegovina (photo by Nikola Zovko, January 2017).

near Imotski (Crveno, Modro, Prološko and Ričice Lakes, River Vrljika) and in the Neretva River, including its larger tributaries (Baćinska Lakes, rivers Matica, Norin and lower part of Neretva) (Mrakovčić et al., 2006, Ćaleta et al., 2015). In Bosnia and Herzegovina, R. basak is spotted in the lower Neretva River drainage (Neretva River and its tributaries the Tihaljina, Trebižat, Jasenica, Bregava, Buna and Hutovo Blato wetland) (Vuković, 1977; Mrakovčić et al., 2006; Sofradžija, 2009; Ćaleta et al., 2015). In the Neretva, it is spotted upriver until the inflow of the Buna River (Kosorić et al., 1983). It seems that the fast flow of the middle and upper Neretva is unfavourable for $R$. basak which prefers moderate to slow current velocities. However, the species does not occur in the reservoirs in the middle and upper Neretva. It is also recorded on the Trebišnjica Channel above the Svitavsko accumulation of the Hutovo Blato wetland (Fig. 2).

\section{Habitat and ecology}

Rutilus basak is a non-migratory species inhabiting a wide range of mostly shallow habitats, such as streams and rivers with moderate to slow currents, lakes, backwaters and artificial water bodies with abundant vegetation. However, it was mostly found in calm and relatively cool $\left(15^{\circ}-17^{\circ} \mathrm{C}\right)$ slow-flowing water. Rutilus basak usually lives in small groups during summer, while during winter it can gather into larger shoals in lakes and in calm areas of rivers. Spawning takes place close to shore on submerged vegetation and hard substrates (Vuković, 1977; Mrakovčić et al., 2006, Tutman and Glamuzina, 2007; Ćaleta et al., 2015).

\section{Biology}

Rutilus basak can reach up to $240 \mathrm{~mm}$ TL (ca. $200 \mathrm{~g}$ ) (Mrakovčić et al., 2006), but usually it grows up to $150 \mathrm{~mm}$ $\mathrm{SL}(30-50 \mathrm{~g})$. Males range from $120-190 \mathrm{~mm}$, females from $116-233 \mathrm{~mm}$ with a maximum observed age of 10 years and a predominance of 4-year-old individuals ranging from 


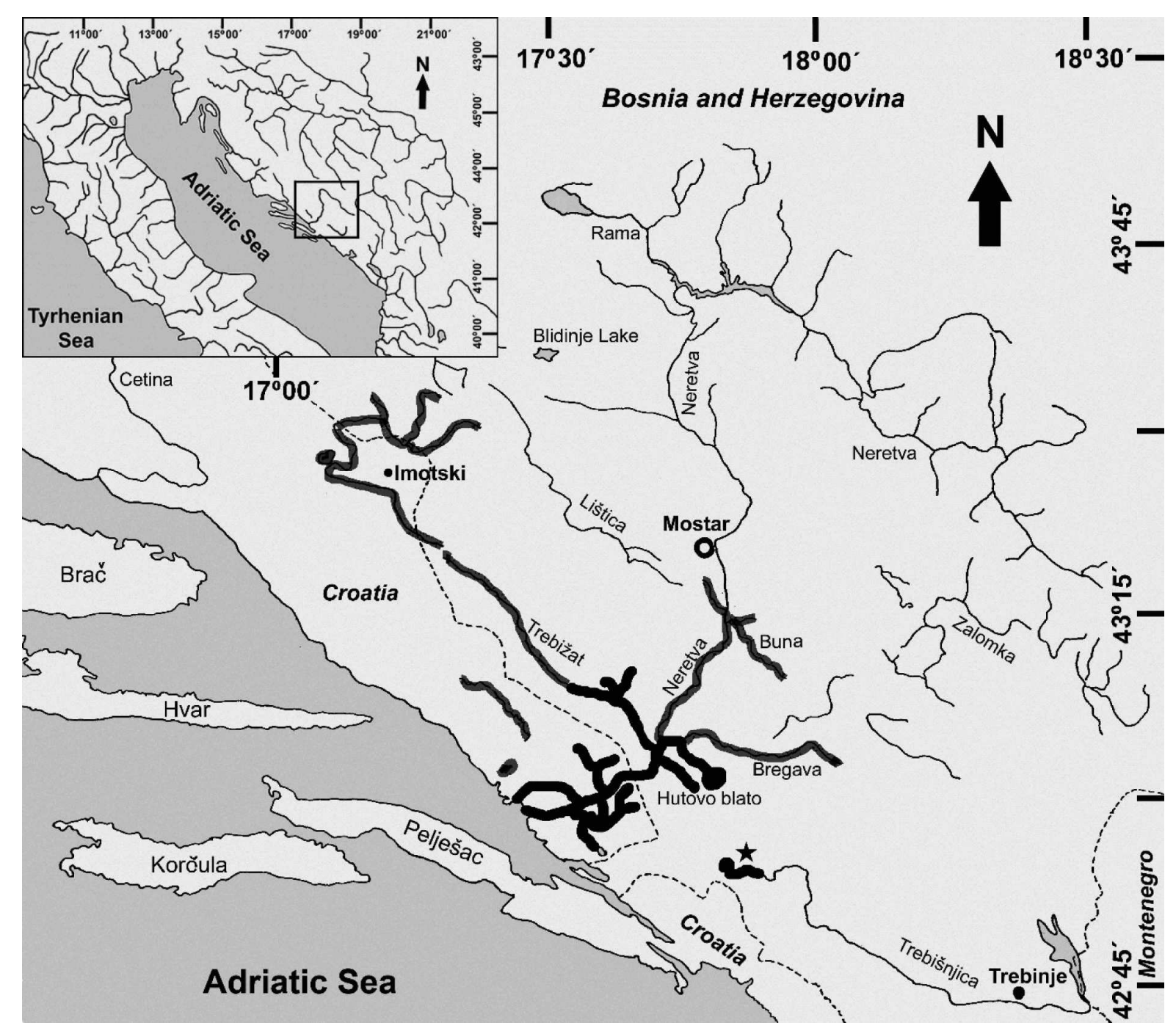

Fig 2. Distribution map of Neretva roach Rutilus basak (Heckel, 1843) (bold black lines) in the Adriatic drainage basin. The star indicates a new record in the Trebišnjica Channel above the Svitavsko accumulation of the Hutovo Blato wetland (Bosnia and Herzegovina).

147 to $157 \mathrm{~mm}$ TL $(22.1 \%)$, within ages ranging from 0 to 10 years in the sample (Tutman and Glamuzina, 2007; Matić-Skoko et al., 2011). The male : female ratio for all fish combined was $0.34: 1.00$ but changed across length classes. Females were dominant in all classes; however, this dominance was less expressed at the beginning of the spawning season $(\mathrm{M}: \mathrm{F}=0.39: 1.00)$ as it seems that females are more exposed to catch in this period. First mature individuals occurred in the $120 \mathrm{~mm}$ length class, and all specimens above $150 \mathrm{~mm}$ TL were fully mature. Total lengths at 50\% maturity (Lm50) were $140 \mathrm{~mm}$ for both males and females. At an estimated age of 2 years, $40.4 \%$ of males and $30.8 \%$ females were mature, while in the third year all individuals were fully sexually mature (Matić-Skoko et al., 2011). The spawning period extended from the end of February until the middle of April, with a peak in the first half of March at temperatures between $12^{\circ}-17^{\circ} \mathrm{C}$. They start to spawn at a water temperature of $13^{\circ} \mathrm{C}$, with females laying up to 100.000 sticky eggs (Tutman and Glamuzina, 2007; Matić-Skoko et al., 2011). Gonad development commenced again in October and continued through January and February. The gonadosomatic index (GSI) reached its minimum values in August and September. There was a high correlation between the GSI and the percentage of ripe and running males and females (Matić-Skoko et al., 2011). The parameters of the allometric length-weight relationship estimated by Dulčić et al. (2009) are $a=0.0053$ (0.0037 $0.0067), b=3.31(3.19-3.43)$ and the correlation coefficient $r^{2}=0.8971$. During the spawning period, nuptial tubercules appear on the head (Vuković, 1977; Sofradžija, 2009). There are only general notes in the published literature on the feeding behaviour and diet of this species, which consists of 
algae, planktonic organisms and small aquatic invertebrates (Vuković, 1977; Mrakovčić et al., 2006; Sofradžija, 2009; Glamuzina et al., 2013).

\section{Population status}

Although common and abundant in the distribution area, no precise data about population trends is available in the literature. The population of this species in the Neretva drainage is estimated to be stable (Mrakovčić et al., 2006; Tutman and Glamuzina, 2007). It can be locally numerous, especially in lakes, like in the Hutovo Blato wetland (Bosnia and Herzegovina) where it represented $15 \%$ of the total fish catches (Kosorić, 1978; Tutman and Glamuzina, 2007). It does not seem to be very common in the Neretva River (Vuković, 1977; Mrakovčić et al., 2006; Tutman and Glamuzina, 2007; Ćaleta et al., 2015). There is no published data for other parts of the distribution area.

\section{Threats}

Despite their distributional area and relative abundance, it is evident that a great deal of general knowledge concerning threats still remains largely unknown. Many threats seem not to impact $R$. basak as the population status is estimated to be stable and the species seems not to be declining. Some of the major threats to aquatic biodiversity are partially defined only for small parts of distribution area - the Neretva River delta in Croatia (Mrakovčić et al., 2006) and the Hutovo Blato wetland in Bosnia and Herzegovina (Tutman and Glamuzina, 2007; Matić-Skoko et al., 2011). At present, the only known situation is for the Hutovo Blato wetland where a long-term trend of loss of environmental quality caused by significant hydrological changes in the water regime is noted. Reduced supply of water from underground sources as well as from the Neretva leads to a general reduction of water levels in the Hutovo Blato, leading to the loss of aquatic habitats (Glamuzina et al., 2001; Tutman and Glamuzina, 2007; Tutman et al., 2013). Another problem arising in the Neretva River drainage is the introduction of non-indigenous species, particularly Lepomis gibbosus, Gymnocephalus cernua and Carassius auratus (Dulčić et al., 2005; Glamuzina et al., 2017). Some of the specific threats that have been identified for populations of $R$. basak in the Hutovo Blato wetland area are loss of spawning and nursery areas due to water capacity lowering which in some areas results in reduction of depth due to siltation (Glamuzina et al., 2001; Tutman et al., 2013). Those populations are also threatened by restricted movements that prevent linkage of local populations to nearby habitats (Matić-Skoko et al., 2011). This phenomenon has led to fluctuations in population strength of $R$. basak in some areas of the wetland (Glamuzina et al., 2001; Tutman et al., 2013). However, it seems that none of these threats have been shown to significantly affect $R$. basak.

\section{Use and trade}

Little information is available on utilization of the species as it has no market value and is of very limited economical interest. Non-targeted species are occasionally caught by artisanal fishers in the Hutovo Blato wetland area. If used at all, $R$. basak is consumed raw and smoked by the local population (Tutman and Glamuzina, 2007).

\section{Conservation actions}

Although, according to the Ordinance on proclaiming wild taxa protected and strictly protected (Law of Nature Protection No. $70 / 05$ and $139 / 08$ ), R. basak is strictly protected in Croatia, no conservation actions have ever been implemented, while in Bosnia and Herzegovina, it is unprotected. The mouth of the Neretva River in Croatia was declared an ornithological and ichthyological reserve, whereas the Hutovo Blato wetland in Bosnia and Herzegovina was given the status of a Nature Park in 1995, and a Ramsar Site in 2001. But likewise, conservation actions have not been performed.

\section{DISCUSSION}

Despite Neretva roach being a relatively abundant fish species (Mrakovčić et al., 2006; Ćaleta et al., 2015), the original data on the ecological traits of the species is mostly derived from older studies (Vuković and Ivanović, 1970; Vuković and Ivanović, 1971; Vuković, 1977; Aganović and Kapetanović, 1978; Kosorić, 1978; Kosorić et al., 1983) with very little new information (Tutman and Glamuzina, 2007; Matić-Skoko et al., 2011). Overall, this study compiled major life-cycle traits of $R$. basak, which can be selected as an indicator to monitor habitat quality and the short, medium and long-term biodiversity management (Tutman et al., 2016). The information obtained suggests that many basic characteristics of this species are still lacking for the comparable analysis of the entire population. Further research should thus be directed to the inventory studies and characterization of the species across its respective ranges. Such information will improve the biological and ecological knowledge of this species and will also allow introduction and adjustment of future management strategies and conservation measures.

\section{ACKNOWLEDGEMENTS}

We are thankful to Nikola Zovko (Director, Natural Park Hutovo Blato), for his generous support during the 
investigation, and to Timothy Adam Shaw from Asian School of the Environment, Singapore, for improving the English in the manuscript.

\section{SAŽETAK}

\section{ŽIVOTNE ODREDNICE NERETVANSKE PLOTICE (BASAK) Rutilus basak (Heckel, 1843) (Pisces, Cyprinidae): BIOLOŠKO- EKOLOŠKI DOPRINOS OČUVANJU BIODIVERZITETA SLATKOVODNIH RIBA}

U radu je dan pregled relevantne znanstvene literature o trenutnom statusu, distribuciji, staništu, ekološkim svojstvima, strukturi populacije i prijetnjama neretvanskoj plotici (Basak) Rutilus basak (Heckel, 1843). Navedena vrsta nastanjuje ograničeno područje jadranskog riječnog sliva u Republici Hrvatskoj i Bosni i Hercegovini. Najveće prijetnje vrsti su gubitci staništa uzrokovani značajnim hidrološkim promjenama vodnog režima na njenom distributivnom području te introdukcija alohtonih ribljih vrsta. Ipak, $R$. basak je prilično rasprostranjena vrsta koju se često nalazi u izobilju. Informacije objedinjene u radu bi mogle unaprijediti znanja o navedenoj vrsti.

Ključne riječi: Jadranski riječni sliv, status, distribucija, prijetnja, očuvanje

\section{REFERENCES}

Aganović, M., Kapetanović, N. (1978): The age structure of populations of some fish species from the Neretva River. Ichthyologia, 10, 1, 1-7. [In Serbo-Croatian/Croato-Serbian].

Buj, I., Ćaleta, M., Marčić, Z., Šanda, R., Vukić, J., Mrakovčić, M. (2015): Different histories, different destinies-impact of evolutionary history and population genetic structure on extinction risk of the Adriatic spined loaches (Genus Cobitis; Cypriniformes, Actinopterygii). PLOS ONE, 10, 7, e0131580.

Crivelli, A.J., Maitland, P.S. (1995a): Introduction. Biological conservation special issue: Endemic freshwater fishes of the Northern Mediterranean region. Biological Conservation, 72, 121-122.

Crivelli, A.J., Maitland, P.S. (1995b): Future prospects for the freshwater fish fauna of the north Mediterranean region. Biological Conservation, 72, 335-337.

Crivelli, A.J. (1996): The freshwater fish endemic to the northern Mediterranean region. An action plan for their conservation. Tour du Valat Publication. Arles.

Crivelli, A.J. (2006): Rutilus basak. The IUCN Red List of Threatened Species 2006: e.T60777A12396138. http://dx.doi.org/10.2305/IUCN.UK.2006.RLTS.
T60777A12396138.en. Accessed on 12 January 2018

Ćaleta, M., Buj, I., Mrakovčić, M., Mustafić, P., Zanella, D., Marčić, Z., Duplić, A., Mihinjač, T., Katavić, I. (2015): Endemic fishes of Croatia. Croatian Environment Agency, Zagreb, 116.

Darwall, W., Carrizo, S., Numa, C., Barrios, V., Freyhof, J., Smith, K. (2014): Freshwater Key Biodiversity Areas in the Mediterranean Basin Hotspot: Informing species conservation and development planning in freshwater ecosystems. Cambridge, UK and Malaga, Spain: IUCN. $x+86$.

Dulčić, J., Glamuzina, B., Tutman, P. (2005): The first record of the ruffe, Gymnocephalus cernuus (Percidae), in the Hutovo Blato wetland, Adriatic drainage system of Bosnia and Herzegovina. Cybium, 29, 2, 205-206.

Dulčić, J., Tutman, P., Prusina, I., Tomšič, S., Dragičević, B., Hasković, E., Glamuzina, B. (2009): Length-weight relationships for six endemic freshwater fishes from Hutovo blato wetland (Bosnia and Herzegovina). Journal of Applied Ichthyology, 25, 4, 499-500.

Glamuzina, B., Tutman, P., Conides, A. (2001): Report on ichthyological survey on Hutovo Blato wetlands. Final report. EU LIFE Third Countries Program, Ministry of Civil Engineering and Nature Protection of Neretva-Herzegovina Cantonal Government, Mostar, B\&H. LTCY/035/ $\mathrm{BiH}$ project: Development of a new management policy for Hutovo Blato wetlands, Bosnia-Herzegovina, 97. [In Croatian].

Glamuzina, B., Pavličević, J., Tutman, P., Glamuzina, L., Bogut, I., Dulčić, J. (2013): Fishes of Neretva River. Mostar/Metković: CEAV/Modrozelena. 263. [In Croatian].

Glamuzina, B., Tutman, P., Nikolić, V., Vidović, Z., Pavličević, J., Vilizzi, L., Copp, G.H., Simonović, P. (2017): Comparison of taxon-specific and taxon-generic risk screening tools to identify potentially invasive non-native fishes in the River Neretva catchment (Bosnia and Herzegovina and Croatia). River Research and Applications, 33, 5, 670-679.

IUCN (2016): The IUCN Red List of Threatened Species. Version 2016-2. http://www.iucnredlist.org. Downloaded on 04 September 2016.

Kosoric, Đ. (1978): The composition of fish populations from Hutovo Blato wetland. Godišnjak BIUS, 31, 69-81. [In Serbo-Croatian/Croato-Serbian].

Kosorić, Đ., Vuković, T., Kapetanović, N., Guzina, N., Mikavica, D. (1983): Fish composition of the Neretva River in Bosnia and Herzegovina. Godišnjak BIUS, 36, 117-128. [In Serbo-Croatian/Croato-Serbian].

Kottelat, M., Freyhof, J. (2007): Handbook of European freshwater fishes. Kottelat, Cornol, Switzerland and Freyhof, Berlin, Germany. 646.

Matić-Skoko, S., Tutman, P., Dulčić, J., Prusina, I., Đođo, Ž., Pavličević, J., Glamuzina, B. (2011): Growth pattern of the endemic Neretvan roach, Rutilus basak (Heckel, 1843) in the Hutovo Blato wetland. Journal of Applied Ichthyology, 27, 3, 813-819. 
Mrakovčić, M., Mišetić, S., Povž, M. (1995): Status of freshwater fish in Croatian Adriatic river systems. Biological Conservation, 72, 179-185.

Mrakovčić, M., Brigić, A., Buj, I., Ćaleta, M., Mustafić, P., Zanella, D. (2006): Red Book of freshwater fish of Croatia. Ministry of culture, State institute for nature protection, Republic of Croatia, 253. [In Croatian].

Sofradžija, A. (2009): Freshwater fishes of Bosnia and Herzegovina. Vijeće kongresa bošnjačkih intelektualaca, Sarajevo. 355. [In Bosnian].

Škrijelj, R., Lelo, S., Drešković, N., Sofradžija, A., TrožićBorovac, S., Korjenić, E., Lukić-Bilela, L., MitrašinovićBrulić, M., Kotrošan, D., Šljuka, S., Gajević, M., Karačić, J. (2013): Red list of Federation Of Bosnia and Herzegovina. Book 3. Greenway Sarajevo and Faculty of Science and Mathematics, University of Sarajevo: www.fmoit.gov. ba/download/Crvena\%20lista\%20Faune\%20FBiH

Tutman, P., Glamuzina, B. (2007): The present status, endangerment and conservation of endemic Neretvan roach, Rutilus basak (Heckel, 1843) (Cyprinidae) from the Hutovo Blato wetland (Neretva River basin, Bosnia and Herzegovina). In: Skaramuca, B., J. Dulčić, B. Glamuzina, M. Mrakovčić, S. Mandić, V. Bartulović, E. Hasković, M. Basta, N. Zovko (eds.), Endangered and endemic fish species in the Neretva, Trebišnjica and Morača river basins. The EastWest Institute and University of Dubrovnik, Dubrovnik: 49. [In Croatian with English summary].
Tutman, P., Glamuzina, B., Dulčić, J., Zovko, N. (2012): Ichthyofauna of the Hutovo blato wetland (lower Neretva River, Bosnia and Herzegovina); status and vulnerability. Ribarstvo, 70, 169-185. [In Croatian with English summary].

Tutman, P., Glamuzina, B., Dulčić, J. (2013): Monitoring the state of flora and fauna after the forest fire, devastation and dissolution of game-keeping services in Hutovo Blato (lower Neretva river) - chapter fish fauna. Ministry of Environment and Tourism Federation of Bosnia and Herzegovina. 53. [In Croatian].

Tutman, P., Hamzić, A., Hasković, E., Dulčić, J., Pavličević, J., Glamuzina, B. (2016): Neretva rudd Scardinius plotizza Heckel and Kner, 1858 (Cyprinidae), endemic fish species of the Adriatic watershed; biological-ecological and conservation traits. Annales, Series Historia Naturalis, 26, 2, 185-190.

Vuković, T. (1977): Fishes of Bosnia and Herzegovina. IGKRO „Svjetlost“, Sarajevo. 203. [In Serbo-Croatian/CroatoSerbian].

Vuković, T., Ivanović, B. (1970): Taxonomic characteristics of the Rutilus rubilio (Bonaparte) from the Lake Skadar and Neretva River basin. Ribarstvo Jugoslavije, 25, 1, 18-20. [In Serbo-Croatian/Croato-Serbian].

Vuković, T., Ivanović, B. (1971): Freshwater fishes of Yugoslavia. Zemaljski muzej SRBiH. 268. [In Serbo-Croatian/ Croato-Serbian]. 